DELAYED RESPONSE 
This page intentionally left blank 


\title{
DELAYED RESPONSE
}

The Art of Waiting

from the

Ancient to the

Instant World

\author{
Yale \\ UNIVERSITY \\ PRESS
}

NEW HAVEN AND LONDON 
Published with assistance from the Alfred P. Sloan Foundation.

Published with assistance from the Louis Stern Memorial Fund.

Copyright (C) 2018 by Jason Farman.

All rights reserved.

This book may not be reproduced, in whole or in part, including illustrations, in any form (beyond that copying permitted by Sections 107 and 108 of the U.S.

Copyright Law and except by reviewers for the public press), without written permission from the publishers.

Yale University Press books may be purchased in quantity for educational, business, or promotional use. For information, please e-mail sales.press@yale.edu (U.S. office) or sales@yaleup.co.uk (U.K. office).

Set in New Aster type by IDS Infotech, Ltd.

Printed in the United States of America.

Library of Congress Control Number: 2018933273

ISBN 978-0-300-22567-9 (hardcover : alk. paper)

A catalogue record for this book is available from the British Library.

This paper meets the requirements of ANSI/NISO Z39.48-1992 (Permanence of Paper). 
For Jonah and Noelle

In Memory of Al Pramschufer 
This page intentionally left blank 